\title{
Albania's Alliance with United States of America After the Cold War
}

\author{
Granit Zela, PhD Candidate \\ "Armed Forces Academy", Tirana, Albania \\ Email: zelagranit401@gmail.com \\ Prof. Assoc. Zaho Golemi \\ "Armed Forces Academy", Tirana, Albania
}

\section{Doi:10.5901/ajis.2014.v3n4p279}

Abstract

The paper aims at providing an insight in the special relationship between Albania and a geographically distant power of global influence such as United States of America. In this context, the goal is to define the existing variables of this bilateral relationship. The analyses focuses on Albania's endeavors to create an Alliance by shedding light on the way how "The Albanian Question" and adaption of Albania's foreign policy to american regional and global interest have a fundamental impact in the US approach towards Albania, while on the other hand, this special relationshship with the American global power constitute a very important strategic priority in order to have the American support to fulfill Albania's aspiration to fully integrate into the Euro-Atlantic structures.

Keywords: Albania's foreign policy, USA, post Cold War area.

\section{Introduction}

After the Cold War, Albania declared the integration into the Euro-Atlantic structures as the major national goal of its foreign policy. In this framework, Albania stated its intention to develop preferential relations with United States of America, as the most trusted ally and the only superpower which enjoys the support of the country's political elite and the population in the country. In order to sustain this special bilateral relationshop, Albania has always tried to provide its full support for the American goals of foreign and security policies in the Balkans and the international scene, within its capacities, by establishing an assymetric relationship of mutual interest. The Albania-US strategic relationship after the Cold War in this paper is divided in four periods:

- 1991-1995, establishing "the special relationship"

- 1996-1998, distancing from the unconditional support for the right wing in the domestic politics,

- 1999-2001, enhancing "strategic relationship"

- 2001-afterwards, relationship in the form of an alliance.

This time framework constitute the basis of our analyses. The goal of this paper is to trace the logic of this assymetric relationship, which although is supported by a very siginificant public sentiment in Albania, indeed, it originates in the strategic interests of these two countries directly related to the new geopolitical dimensions of Balkans and the mutual interests that the American "great power" and the Albanian "small power" have in the region.

\section{Establishing the "Special Relationship" 1991-1995}

On March 15, 1991, USA re-established the diplomatic relations. The visit of the US Secretary of State James Baker on July 31, 1991 to Albania made visible another important factor to this relationship: support of the Albanian public for US. The extraordinary reception of US Secretary of States James Baker in Tirana demonstrated that the communist propaganda to create the image of US as an enemy of Albanian nation had proven false, while United States were perceived by the public as the country that embodied the aspiration of Albanian citizens for democracy and prosperity as well as the protector of the Albanian national interests in a destabilized region and fragile economic situation in the country. After a long period of the communist diplomacy of isolation, Albania returned to the regional and international scene while US opened the Embassy on October 1, 1991. Edward William Rayerson was the first American Ambassador 
in Albania after 52 years. .(Arvizu Alexander, 2011:1). He gave a very important contribution in supporting the newly formed opposition that came to power on March 31, 1991.

The conflict in Bosnia and Herzegovina and Croatia intensified in 1993 made USA and other western powers interested to have Albania a country that did not support any nationalist Albanian armed rebellion in Kosova and Macedonia. In exhange to Albania's support to preserve the status quo in the Balkans, USA was providing economic and political support. On the other side, Albania aimed at developing a special relationship with USA especially in the security area. Albania signed the Memorandum of Understanding on Military Relations with USA on October1993, "the first of that kind with a former communist country," establishing US military relations with Albania"(Meksi E, 2003: 21) which was considered by US as expansion of "the american military positions in the Balkans"(Perreti M, 2000:37).

Albanian-American relations reached their peak during the period of bombardment in Bosnia and Herzegovina while Albania offered "necessary assets to fulfill all the US and NATO needs" in terms of military engagement. Former American president George H.W. Bush had received in a meeting President Berisha on 1992, and President Bill Clinton met him in the White House on September 12, 1995, a few weeks before the peace talks held in Ohio, on November 1 of theat year. Despite the "excellent relations" between two countries, Kosova Issue did not become part of the conflict resolution. This due to the complicated security equation in $\mathrm{B}-\mathrm{H}$ that was endangered by an additional variable of conflict by defining in this way the limit of the this strategic relationship. The strategic importance of Albania in the regional context diminished in the period of Peace Talks and remained at those levels until the forthcoming armed conflict in Kosova.

\section{Distancing from the Unconditional Support for the Right Wing in the Domestic Politics, 1996-1998}

Parlamentary elections in May 1996 marked a change of US perception for domestic politics in Albania. Up to this time period, the Democratic Party enjoyed uncoditional support and US representatives in the country openly stated their desire to have the DP remain in power. After the problems appearing in the election process, there were critics to US administrations in Tirana for turning a blind eye to the authoritarian regime of DP leader Berisha as "a support for a political force in a pluralist political process." US changed its approach by expanding the relations with other political factors of the domestic political scene while Albania was suffering an economic trauma. US redefined its engagement in the context of the wider regional context. In march 1997, Albania suffered from an domestic economic and security collapse at a time when US and western powers had their troops in B-H and Macedonia. US supported the draftresolution for an European international police presence in Albanian to aid the recovery of the country in the UN Security Council which was the first precedent for the creation of such a coalition to intervene in cases of regional crises in the future.

\section{Enhancing "Strategic Relationship" 1999-2001}

The main US and European koncern after the conflict in B-H was Albania's stance toward the Kosova conflict, since it would have wider consequences in the region. Albania remained neutral and after the start of NATO bombing on March 23, 1999 against the repressive regime of Milloshevic, Albania was hosting the greatest number of refugees who fled from Kosova to escape from the ethnic cleansing of Milloshevic and his strategy to disbalance the region. US was among the first countries to provide humanitarian and personnel support while in the "Allied Harbour Operation", US was providing the core military capacities to conduct the majority of air strikes. The contribution of the american military power was irreplaceable in ending the last bloody conflict in the dissolution process of former Yougoslavia.

The US pro sentiments among Albanians increased rapidly while US became one of the main supporters of Kosova independence within the Contact Group. The establishment of an international administration in Kosova after the NATO intervention favored the future of the Kosova and Albania was careful not to portray herself as a supporter of Albanian nationalism but a country contributing to regional stability and security in support of development of close economic, social and political relations among the Albanians in the region and by refusing the violent change of region borders. US Department highlighted the "moderating role" of Albania in UN in the process of negotiations on the future of Kosova."

\section{Albanian-US Alliance after 2001}

Terrorist attacks of September 11, 2001 against USA changed the american foreign policy priorities by focusing them on 
"War against Terror."26 Europe was divided in its stance regarding the military intervention in Iraq while Albania was among eight european states that declared its support against regime of Saddam Hussein and sent troops in Iraq after the approval by Assembly on March 13, 2003. ${ }^{46}$ The contribution of Albanian troops exceeded the limited quantative participation since this support had a special value considering the secular nature of Albanian state and the muslim religion of Albanian population majority strongly supporting US policies. ${ }^{55}$

Having the US support, in May 2003, the NATO partner countries: Albania, Croatia and Macedonia signed "Adriatic Charter" which constituted a military partnership as well as a clear sign of the american support for these countries in conformity of the NATO "Open Door Policy."(Gredešic, Ivan, 2004:104). Albania signed a bilateral agreement with USA in 2003, to exclude the citizens of both parties from the obligation of submitting them to International Justice Court which was criticised by the EU officials and strongly suppported by all Albanian political parties (Erzeni Orest, 2003). It provided asylym for five ethnic chineze muslim Uighurs deported form Guantanamo by helping US to keep them outside their territory while they could not be returned to their country since their lives would be endangered. US State Department considered it "an important humanitarian gesture" (McCormack Sean, 5 May 2006).

The great welcome demonstarted during the eight hour visit of President Bush in July 10, 2007 to Albania was surprising for the media and world public opinion (Lucas Peter,2007) and Albania expressed the significance of this relationship by showing itself as "maybe the most pro-american country in the world". (Tarifa Fatos, 2005). Captain Feti Vogli lost his life in 2011 during a joint military operation of Albanian and American special troops in Kandahar, Afghanistan. Albania has already sent to Afghanistan the fifth round of "Eagle 5" combat forces as well as OMLT forces to contribute in training the Afghan police. Albania is at present a strong US supporter and participates in the Coalition Operations in Iraq while it has increased its contribution to Afghanistan while USA is perceived as a trusted ally.

\section{Conclusions}

In the time period 1991-2012, Albania was visited by four US Secretaries, James Baker, (1991) Madeleine Allbright (1999) Colin Powell (2001), Hillary Clinton (2012) and former US president George W. Bush (2007). Every time that a high US official visits Albanian, journalists, politicians, and members of the reserach community try to trace the basis of this special relationship, considering it as a "case study" in the field of politics. Based on the methodology used in this brief panorama of the US-Albanian relations after the Cold War, our analyses reaches the following conclusions.

After the Cold War, US engagement in the Balkans was part of the american interest to support the former members of the Warsaw Pact in their endeavors of radical transformations in establishing liberal democracies and free market economies. United States were considered by Albania' political elite as a very important ally for their national interests: regime change, economic aid, a strategic ally to ensure Albania's security and support for the "Albanian Question" in the region.

Albania did not become part of conflicts in the region but adopted a careful and cooperating foreign policy in conformity with American interests for the regional stability. An economic partnership and a strong American presence in the Albanian politics prevented Italian and Greek domination in the domestic economic and political sphere.

USA provided a contribution in the security field, transformation of the Albanian army and Albania's membership in NATO by establishing the foundations of the Alliance. Sympathy for USA was dramatically increased after the NATO intervention in Kosova as another decisive historical moment in support of Albanians after the intervention of Woodrow Wilson in 1919 to protect existence of an Albanian state in the region while facing the desire of neighbor states to absorb its territories.

After the terrorist attacks of September 11, 2001, USA was considered by Albania as "an indispensable ally". Albania was engaged with military troops in Afghanistan and Iraq within the limits of its capacities in exchange of support for Albania's foreign policy goal of Euro-Atlantic membership. Albania's support after the intervention in Iraq served to increase US led coalition legitimacy especially if one considers Albania's secular nature as a country of Muslim population majority.

Albania plays at the present a moderating role in the region and supports negotiations between Kosova and Serbia, Macedonia's membership into NATO and good neighborly relations having the major goal of full-fledged integration into EU. USA support is focued on the increasing professional standards in the war against international and organised crime, war against terrorism, weapon and human trafficking, as well as to strengthen Albanian army and intelligence capacities, Strategic Defence Review etc as part of a consolidated relationship in the framework of the regional context and mutual interests that guarantee a relationship in the form of an alliance. 


\section{References}

Arvizu A, Alexander, (2011) US-American Relations, Building the Future, Tirana, October, 6, 2011.

Lucas Peter, (2007) "Why Albanians love America", New York Times, June 14.

Meksi Ermelinda, (2003) "The Albanian Dimension of Integration", Albanian Institute for International Studies, Tirana.

McCormack, Sean, (2006), "Release of Five Ethnic Uighurs from Guantanamo", The U.S. Department of State Press Statement, 5 May.

Tarifa, Fatos, (2005), "Opinion: Albania Stands with the U.S. in Iraq", The Washington Times, republished in Albanian Daily News, 28 March.

Gredešic, Ivan, (2004), '"US-Adriatic Charter Partnership: Securing the NATO Open Door Policy', Politicka Misao, vol. 41.

Report (2004), Commission of the European Communities "Albania: Stabilisation and Association" Brussels.

Erzeni, Orest, (2003) "ICC Agreement Wins Strong Support for Albanian Political Parties", Southeast European Times.

Perretti Michel(2000), "The Stability Pact and Its Role in Albania's Road towards Integration with the European Union", Albanian Institute for International Studies. Tirana.

Powell: US, Albania to Strengthen Relations.

http://english.peopledaily.com.cn/200305/03/eng20030503_116174.shtml

http://www.balkaninsight.com/en/article/warm-welcome-awaits-clinton-in-albania

http://www.brecorder.com/top-news/1-front-top-news/88563-clinton-to-urge-albania-to-unite-behind-eu-target-.html 